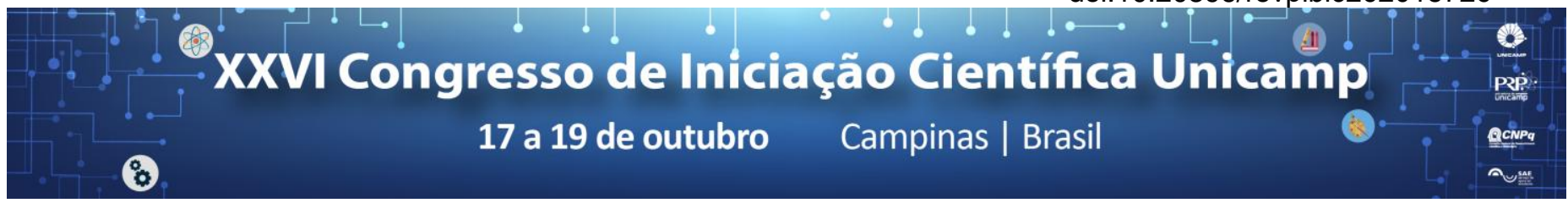

\title{
Investigation of levels of assertiveness and its association with self-esteem among undergraduate students in dentistry.
}

\section{Juliana Benine Warlet Rocha*, Karine Laura Cortellazzi, Rosana de Fátima Possobon.}

\begin{abstract}
It was investigated the level of assertiveness among students of the undergraduate course in Dentistry of FOP-Unicamp and verified its association with self-esteem and other socioeconomic variables. The mean age of the students was 21 years, of which $79.16 \%$ were female and $43.22 \%$ had low self-esteem. Regarding assertiveness, $82.30 \%$ presented adequate characteristics, any of the participant students had low assertiveness levels, and $17.70 \%$ had levels associated with aggressive characteristics, and there were no significant association between assertiveness and self-esteem.
\end{abstract}

\section{Key words:}

Assertiveness, Self Concept, Students, Dental.

\section{Introduction}

The term assertiveness consists of an association between the way in which the individual expresses his feelings and asserts his own rights and beliefs and the way he deals with the opinion of others without violating the right of other individuals to express themselves.

Studies relate low levels of assertiveness at unfavorable rates in social performance among university students and this situation may be associated with higher and lower degree of self-esteem among students.

The goal of this research was investigate the level of assertiveness among students from Piracicaba Dental School - Unicamp and verify its association with self-esteem. Results and Discussion

\section{Results and Discussion}

A total of 192 undergraduate students in Dentistry of the Dental School of Piracicaba (FOP-Unicamp), aged between 18 and 35 years, from the 5 years of the undergraduate course in 2017 participated in the study.

The students were invited to participate in classroom and filled the instruments Rathus Assertiveness Scale (RAS) and Rosenberg's self-esteem scale. They also filled questions related to the age, place and origin of residence, the age and schooling of the father and mother, and the monthly income based on the socioeconomic questionnaire by Meneghim et al.

A descriptive analysis of the data was carried out through frequency and percentage tables, measures of central tendency and dispersion. Gross analyzes, estimating the Gross Odds Ratios and 95\% Confidence Intervals, were performed to test the association between the dependent variable (assertiveness) and the other independent variables.

The statistical tests were performed by the program Bioestat 5.0. and a significance level of $5 \%$ was considered.

The mean age of the students was 21 years, of which $79.16 \%$ were female and $43.22 \%$ had low selfesteem. Regarding assertiveness, $82.30 \%$ presented adequate characteristics, any of the participant students had low assertiveness levels, and $17.70 \%$ had levels associated with aggressive characteristics, and there were no significant association between assertiveness and selfesteem.

Chart 1. Association between independent variables (age, sex, age of father and mother, degree of education father and mother, income and self-esteem) and a dependent variable (assertiveness) divided into its appropriate and aggressive levels.

\begin{tabular}{|c|c|c|c|c|c|c|c|c|}
\hline \multirow[b]{3}{*}{ Variável } & \multirow[b]{3}{*}{ Categoria } & \multicolumn{4}{|c|}{ Assertividade } & \multirow[b]{3}{*}{ OR Bruto } & \multirow[b]{3}{*}{ IC $95 \%$} & \multirow[b]{3}{*}{ pvalor } \\
\hline & & \multicolumn{2}{|c|}{ Adequada } & \multicolumn{2}{|c|}{ Agressiva } & & & \\
\hline & & $\mathbf{N}$ & $\%$ & $\mathrm{~N}$ & $\%$ & & & \\
\hline \multirow{2}{*}{ Idade } & $\leq 21$ anos & 94 & 81,03 & 22 & 18,97 & 0,80 & $0,37-1,73$ & 0,7110 \\
\hline & $>21$ anos & 64 & 84,21 & 12 & 15,79 & 1,00 & & \\
\hline \multirow{2}{*}{ Sexo } & Feminino & 129 & 84,87 & 23 & 15,13 & 2,12 & $0,93-4,84$ & 0,1117 \\
\hline & Masculino & 29 & 72,50 & 11 & 27,50 & 1,00 & & \\
\hline \multirow{2}{*}{ Idade pai* } & $\leq 51$ & 79 & 82,29 & 17 & 17,71 & - & - & - \\
\hline & $>51$ & 79 & 82,29 & 17 & 17,71 & - & - & - \\
\hline \multirow{2}{*}{ Idade mãe } & $\leq 49$ & 79 & 79,80 & 20 & 20,20 & 0,77 & $0,36-1,65$ & 0,6458 \\
\hline & $>49$ & 71 & 83,53 & 14 & 16,47 & 1,00 & & \\
\hline \multirow{2}{*}{ Instrução pai } & Sem ensino superior & 49 & 83,05 & 10 & 16,95 & 1,00 & & \\
\hline & Iniciou o ensino superior & 105 & 82,03 & 23 & 17,97 & 0,93 & $0,41-2,10$ & 0,9709 \\
\hline \multirow{2}{*}{ Instrução mãe } & Sem ensino superior & 51 & 80,95 & 12 & 19,05 & 1,00 & & \\
\hline & Iniciou o ensino superior & 101 & 82,11 & 22 & 17,89 & 1,08 & $0,49-2,35$ & 0,9948 \\
\hline \multirow{2}{*}{ Renda } & $<6$ salánios mínimos & 78 & 84,78 & 14 & 15,22 & 1,43 & $0,66-3,09$ & 0,4693 \\
\hline & $\geq 6$ salánios mínimos & 70 & 79,55 & 18 & 20,45 & 1,00 & & \\
\hline \multirow{2}{*}{ Autoestima } & Baixa & 72 & 86,75 & 11 & 13,25 & 1,00 & & \\
\hline & Alta & 86 & 78,90 & 23 & 21,10 & 0,57 & $0,26-1,25$ & 0,2223 \\
\hline
\end{tabular}

\section{Conclusions}

We conclude with this study that there is no significant association between assertiveness and selfesteem.

\section{Acknowledgement}

To PIBIC-CNPq for granting the Scientific Initiation grant. 